\title{
Angelica Camacho*
}

Tecnológico de Monterrey, Campus Querétaro

\section{THE WAR IS NOT OVER UNTIL IT IS OVER. CONTEMPORARY FILMS AS A MEANS OF NATIONAL IDENTITY CONSTRUCTION AND MEMORY IN POLAND}

\begin{abstract}
Films are an important source of symbolism. They help people construct a national identity and memory of the past. Contemporary film productions in Central and Eastern Europe which focus on themes such as World Wars I and II and post-communism, rewrite and redefine the national identity of citizens. It is important to analyze and discuss these films as a way to gaining a richer understanding of the discourses of national identity. In the Polish film Rose (Róża) by Wojciech Smarzowski, the main female character is the recipient of an imposed identity before and after World War II. On the other hand, in the Polish film In Darkness director Agnieszka Holland tells the story of a man who helps Jews hide in the sewer system. Holland and Smarzowski portray Poles as individuals willing to risk their lives for Jewish people: this is also national identity construction.
\end{abstract}

Keywords: national identity, ethnicity, history

The Polish film industry has recently produced movies that rethink the World War II and the Holocaust. These themes are constantly in the minds of film directors, who represent the voice of the Poles and through them retell the role they played in this period of history. In this paper I will discuss Wojciech Smarzowski's Rose and Agnieszka Holland's In Darkness and how, from my perspective as an outsider, they stress the idea that it was a hard time for the Polish people as victims of subjugation from the East and the West. Having a hard time to survive, little could have been done to help others, such as Jews and Masurians. Nevertheless, the Poles did help when they could, despite the risk of getting caught and being executed. The international claim that the Poles looked the other way instead of helping those with an even greater disadvantage is replied to with films that cleanse the image of the Polish citizens. The films Rose and In Darkness represent an alternative interpretation of WWII where the Poles themselves are portrayed as victims during the Russian and German occupation. Under those circumstances they could only try to survive, but even in that case, they did what they could to help others.

* Corresponding author: Angelica Camacho, Profesora de Tiempo Completo, Departamento de Relaciones Internacionales y Formación Humanística, Tecnológico de Monterrey, Campus Querétaro, Mexico; e-mail: acamach@itesm.mx. 


\section{NATION AND NARRATION}

Art like films are cultural artifacts that give an alternative version of history to shape the idea of a nation. A nation is told: it is narrative, films, poetry, metaphors. Characters that are exalted as heroes. It is a social construction, a reality based on chosen symbolic elements that create a reality. This makes the study of nations even harder because each one of them has to be studied not only from its history, but also on the official discourses and art in general: "Traditional histories do not take the nation in its own word, but, for the most part, they do assume that the problem lies with the interpretation of 'events' that have certain transparency or privilege visibility" (Bhabha 2010). Bhabha's proposal is to see nation-ness as a form of social and textual affiliation and wants to emphasize "the complex strategies of cultural identification and discursive address that function in the name of 'the people' and 'the nation"” (Bhabha 2010) because "the telling of the individual story and the individual experience cannot but ultimately involve the whole laborious telling of the collectivity itself" (Bhabha 2010).

The nation is narrated in media res, "the space of the modern nation-people is never simply horizontal" (Bhabha 2010) it is conceived in a present time that finds in the past the symbolic tools that will be used by the teller to explain who the members of the nation are and foresee the future, but "history can be half-made because it is in the process of being made" (Bhabha 2010). We need a different time of writing "that will be able to inscribe the ambivalent and chiasmatic chasmic intersections of time and place that constitute the problematic 'modern' experience of the western nation" (Bhabha 2010). When we study the nation, national feelings and nation-ness, we must understand time as double and divided, says Bhabha, and we must question the horizontal and homogenous view. Films help to do this, they use the past to create stories that re-interpret the historical facts.

The nation is not only a project written by the elites. Bhabha says that the nation is "an agency of ambivalent narration that holds the culture at its most productive position" (Bhabha 2010), and proposes the idea of developing analysis for this ambivalence since "the ambivalent, antagonistic, perspective of nation as a narration will establish the cultural boundaries of the nation so that they may be acknowledged as containing thresholds of meanings that must be crossed, erased, and translated in the process of cultural production" (Bhabha 2010). This would allow us to understand each nation better because every foundational fiction is the origin of national traditions that become "acts of affiliation and establishment as they are moments of disavowal, displacement, exclusion, and cultural contestation" (Bhabha 2010). Narratives, then, are key elements for us to imagine the nation, and discursively construct its historic significance. We must study how the nation is portrayed not only in the discourses of the elites, but also in films. H. Bhabha in "DissemiNation: time, narrative, and the margins of the modern nation" raises the importance of gathering stories that contribute to shape the idea of a nation:

Gatherings of exiles and emigrés, and refugees, gathering on the edge of 'foreign' cultures; gathering at the frontiers; gatherings in the ghetto's cafés of city centres; gathering in the half-life, high-light of foreign tongues, or in the uncanny fluency of another's language; gathering the signs of approval and acceptance, degrees, discourses, disciplines; gathering the memories of undevelopment, of other worlds lived retroactively; gathering the past in a ritual of revival; gathering the present. 
Also the gathering of people in the diaspora: indentured, migrant, interned [...] immigration status [...] In the midst of these lonely gatherings of the scattered people, their myths and fantasies and experiences, there emerges a historical fact of singular importance (Bhabha 2010).

Bhabha's intention is to include 'the scattered' people, those in exile and migrants who, for some reason, had to leave their homeland. Films provide a metaphorical idea of both nations, the one form the past (during the war) and the current one. Here:

The discourse of nationalism is not my main concern. In some ways it is the historical certainty and settled nature of that term against which I am attempting to write of western nation as an obscure and ubiquitous form of living the locality of culture [...] a form of living that is more complex than 'community; more symbolic than 'society' [...] less patriotic than patrie; [...] more mythological than ideology [...] more hybrid in the articulation of cultural differences and identifications [...]. I am proposing this cultural construction of nationess as a form of social and textual affiliation (Bhabha 2010).

It is the artist (as part of the people) that can give another version of the nation, it is another way to narrate it, the other face of Janus, "The people are neither the beginning or the end of the national narrative; they represent the cutting edge between the totalizing powers of the social and the forces that signify the more specific address to contentious, unequal interest and identities within the population" (Bhabha 2010).

Bhabha stresses the importance in the performative functions of language: it is not just descriptive, but it is the creation of a different reality that comes into existence when it is told. Visual language is even stronger in the creation of such reality. Stories told by film directors who are not concerned with historicism, sociological commitments, official texts to be included in schools, or speeches of national leaders are free of labels, trends of thought, political affiliations and so on. It is the way they contribute to writing the history and idea of a nation, "The secular language of interpretation then needs to go beyond the presence of the 'look', that Said recommends, if we are to give the nonsequential energy of lived historical memory and subjectivity its appropriate narrative authority" (Bhabha 2010). The nation is, then, an agency of ambivalent narration, the place where nature and history have meaning to fill people with the spirit of belonging.

People who are part of a nation live in a world where the different actors have no idea of each other, they only know they share "a function of this synchronicity of time which is not pre-figurative but a civil contemporaneity realized in the fullness of time" (Bhabha 2010). Even if the people-nation is divided, it can assume its role in the social imaginary, a form of 'democratic anonymity'. There is a profound liberation of individuals when they are conscious of their narrative, this means a discourse of minorities that emerges and speaks between times and places. Directors' have their own versions, and respond to the official discourse. With novels, films, memoirs, and stories of their lives, they give a different version "For the political unity of the nation consists in a discontinual displacement of its irredeemably plural modern space, bounded by different even hostile nations, into a signifying space that is archaic and mythical, paradoxically representing the nation's modern territoriality, in the patriotic, atavistic temporality of Traditionalism. Quite simply, the difference of space returns as the Sameness of time, turning territory into Tradition, turning the People into One" (Bhabha 2010). 
Montserrat Guibernau says that a personal narrative connects all these experiences and presents them as a 'life story',

quite often individuals introduce some variations when narrating their 'life story' to themselves and when presenting it to others with the aim of enhancing or highlighting coincidence or opposition to the other. By narrating their life story, individuals seek to project a certain self-image that is bound to the subject to some degree or variation depending upon the individual's aims and the audience being targeted. Telling our life story involves consciously emphasizing certain aspects and events while neglecting, reinterpreting or even deleting others to attempt to launch a specific self-image (Guibernau 2013: 18).

Through the lives of Róża, Tadeusz, and Poldek, storytelling becomes personal and re-constructs people's identity and transform their self-image. We could even say that the creating of their autobiography is at times a healing process.

\section{ETHNICITY, NATIONS AND IDENTITY}

Ethnic groups are defined by M. Weber as: "those human groups that entertain a subjective belief in the common descent because of similarities of physical type or of customs or of both, or because of memories of colonisation or migrations" (Guibernau and Rex 2010: 2). Within human groups, stories of how they came into being are told so members can feel they belong to a particular community. These stories are charged with symbolic characters, myths, and situations that help to construct the idea of a citizen of a given community. As M. Guibernau and J. Rex write, "[ $t]$ he concepts of ethnicity and nationalism imply a certain commonality among members of a group, the ethnic group in one case, the nation in the other; these are constructed symbolically and presuppose the existence of the boundaries that separate one group from another" (Guibernau and Rex 2010: 5). The idea of a common origin is fundamental for a nation's members, therefore in the case of Poland, people who do not belong to the Slav ethnic group will never be able to share that nationality.

Territory is a key element is determining nations and the people who live in it. For Poles who lived in Silesia or Masuria, the desire to recover the motherland was the reason for the uprisings at different times (Davies 2005). Once a nation is defined, once it is invented as an imagined community, people will feel that they share the same myths, ancestry, history and culture (Anderson 1983) yes, but not all Poles took part in that process. Some of them lived in a different state (German-Masiurians) and they do not have the same feelings towards the nation. When memories of a common past are strong, the feeling of belonging to that nation will justify actions against "those who are obviously different... [who] are avoided and despised or, conversely, viewed with superstitious awe" (Guibernau and Rex 2010: 17). Poland was divided and some groups of people were not included in these processes. By the end of World War II, the Masuria Region became part of Poland, but its people did not really become a part of the Polish community. Cultural artefacts did not help Masurians to be considered as equals, and they did not feel the same as other Poles. On the contrary, they represented the enemy, even though they did not agree with the Nazis. As in the other ethnic 
conflicts, the members of the minority were described and defined as non-Poles and traitors because they joined the German army during the war. Unable to speak for themselves, yet willing to stay in Masuria, they had to show that they could be considered as Polish citizens, otherwise they would be expelled from the country: "Until a short time ago most Poles in Upper Silesia had no strongly developed sense of Polish nationality that was antagonistic to the Prussian state which is essentially the German language" (Guibernau and Rex 2010: 26). Native people in the Masurian region, before World War II were loyal to the Prussian state, but they did not necessarily felt neither German nor were they devoted to the Reich. It was clear for them that they did not have the need to separate from German-Prussians nor reject their language.

Among the Baltic Germans we find neither much of a sense of nationality amounting to a high valuation of the language bonds with the Germans, nor a desire for political union with the Reich; in fact, most of them would abhor such a unification. However, they segregate themselves rigorously from the Slav environment, and especially from the Russians, primarily because of status considerations and partly because both sides have different customs and cultural values which are mutually intelligible and disdained (Guibernau and Rex 2010: 26).

After World War II, the people of Masuria were strangers in their own land since it had become Polish territory. In this case, the other is an identity constructed by the Poles and the Russians. Ethnicity can be constructed since it is connected with a group with the same past, myths and ancestors. Even though people can look the same, when a majority or a dominant group labels another, the minority will not be assimilated, as "the ethnic identity becomes an imperative status, an ascribed aspect of their personhood from which they cannot escape entirely" (Eriksen in: Guibernau and Rex 2010: 47).

Films like Rose and In Darkness are examples of how a country can define a person either as a member or as an enemy of a nation. In both films we see ethnic conflict between Poles and Masurians, Jews and Nazis. Jews and Masurians are no longer seen as part of the land where they live or as groups who are unable to live in the same land as Poles. They do not share the same myths, past, traditions, or religion with the dominant groups. Masurians are labelled as Germans, no longer as Prussians. Similarly Jews are not seen as Poles; they are outsiders, strangers (Gudykunts and Yun Kim 1995) and members of a different "race", with a different genetic background and with a different historic memory. They are defined as strangers, not the same as "pure" Poles.

\section{THE WAR IS NOT OVER WHEN IT IS OVER}

Rose is a film that portrays the life of a woman who will be the symbol of Masurians suffering from an imposed identity, first by Germans and later by Poles and Russians. Róża survives World War II in the Prussian region of Eastern Masuria, which later became part of Poland. Tadeusz, a former member of the Armia Krajowa (AK), arrives at Róża's farm after the end of the war. He witnessed the death of Różas' husband during the war and has some belongings that he wants to return to Róża. Before he sees her, the Lutheran pastor 
talks to Tadeusz and tells him that she had recently lost her daughter and that she had been mistreated by other people.

Róża is a symbol of an unwanted person in the new Polish People's Republic under the Russian occupation. She is the widow of a native man who also was a German soldier. Tadeusz is also a widower, as he lost his wife when she was raped and executed by German soldiers. Since ethnic groups are constructed on the basis of history, symbols, and customs, the new Pole becomes a person who shares with others a common past, ancestors and the ideals of the new Polish People's Republic. In order to survive, both Tadeusz and Róża have to show they share those customs and ancestors. In this case, Róża's declared ethnicity does not matter. The imposed identity is enough for her to be treated as a whore and a traitor of the Poles and the Masurians.

When Róża was in Prussian Masuria, she had no problem with her identity. However, the new territory is enough to transform her into an enemy, and as a consequence she can no longer say who she is, how she identifies herself. She is in the hands of the other German Masurians, the Poles who want to rebuild the country and the Russians who came to Poland to impose a new government. Róża is no longer a bearer of the Polish/Masurian culture but in the eyes of others, she is an enemy. She was married to a German soldier when the Russians invaded her farm, therefore, she is also an enemy of the Poles because she was married to a man who joined the German army. The new Polish nation, in the minds of the authorities and the common Poles, is charged with emotional symbols and Róża has no place in this new nation. "The nation thus became an emotionally charged object and nationalism emerged as an ideology centred upon sentiment of belonging to a particular community and the subsequent desire to see it flourish" (Guibernau and Rex 2010: 4). The shared idea of a new nation promoted the homogenization of its members and Róża is hardly capable of belonging. The only way to achieve it is by getting married to Tadeusz and letting him live on the farm. However, in this way she becomes the kind of person that the Masurians would reject.

Tadeusz, on the other hand, has migrated to Róża's farm. On his way we see him looking for useful things in an abandoned car. He finds a rifle and dollars in a can. This money is important because he will use it to help Róża, and to buy things from a trafficker who turns out to be a spy from the new Polish government. In this film, we see people trying to run away from their captors (soldiers) and Tadeusz sees them but is unable to help them. As one of them hides lying on the ground, he sees Tadeusz and Tadeusz sees him, but neither of them speak. Smarzowski shows the kind of situation Poles had to go through, where there were no possibilities to help others. As he keeps looking for Róża's farm, he sees men robbing Masurian houses; the lack of music stresses Tadeusz's loneliness.

On the farms, people have displayed Polish flags as a way of protecting themselves. Prussia, which was dominated by Germans and Masurians, had to go through a Germanization process before the war. Some of those people preserved the Polish language, culture, music, and literature. However, by the end of the war, Poles saw them as those who fought with the German army. As I mentioned before, it is not only Poles who saw them as enemies but the Russians accentuated their imposed identity as traitors as well.

Tadeusz is invited to stay and help Róża get rid of the mines planted on her potato fields. Although the war is officially over, it is not over yet in the region. The re-organization of 
the country under the Russian occupation makes the Prussians an ethnic group that has to be expelled. German becomes the enemy language and the Prussians are forced to speak Polish. Ethnicity as a social identity is based on "descent" and "cultural difference" (Fenton 2010: 3). As Fenton says, ethnicity is a social construction "of descent and culture, the social mobilization of descent and culture and the meanings and implications of classification systems built around them" (Fenton 2010: 3). People do not necessarily posses ancestry, they invent it and construct communities founded by the new symbols that will contribute to the birth of the new nation (Fenton 2010).

According to Michael E. Brown (2010), ethnic groups must first have a name, like Masurians or the new Poles. Second, the members of the group must believe they have a common ancestry. Third, its members must share the same ancestry. Polish historic memory goes back to the $10^{\text {th }}$ century (Davis 2005) with the birth of the Polish Empire as legitimated by the Pope in Rome. At that point the conversion to the Roman Catholic religion represented a way of being protected by other kingdoms. Ever since that time, they have rejected and expelled those of different religions. Other things an ethnic group must share are its language, religion, customs, territory, and it must think of itself as a group. The ethnic conflict we see in this film deals with the two groups. On the one hand we see the Poles under the new communist authority. This makes them one group but not one people, since the identities as members of the socialist nations are now imposed. For example, when Tadeusz talks to Róża for the first time, she is aggressive and sees him as another Pole cominges to take over the farm. This aggression is shown when two different groups live in the same territory. On the other hand, it becomes a major ethnic conflict because "authorities must be too weak to keep groups from fighting and too weak to ensure the security of individuals groups" (Brown 2012: 94). In this case, we see a Polish authority without autonomy, unable to make a decision on its own.

When empires or countries break up "ethnic geography frequently creates situations that favour the offence over the defence [...] Often groups will try to expel pockets of minorities from the territory" (Brown 2012: 94). There is one scene between Tadeusz and a Polish soldier, who now belongs to the new army of the People's Republic of Poland. When he recognizes Tadeusz, with whom he was in the Home Army (Armia Krajowa), he says that Masurians are traitors, strangers and Hitler's supporters. He refers to them as "Hitler's fools", "Hitler mugs" or "Lousy Luthers".

When Tadeusz goes to the barber, the barber compares Poles to vultures who have come to take over the farms and land. In the past they were seasonal workers but now they are stealing what the Germans left behind. This is the birth of the new Poland, a nation that came into existence a few years before, in November 1918; a country that recovered part of its land that was populated by Prussians; a society dominated by Russian authorities; a nation receiving displaced people from Ukraine now populating Masuria. The redefinition of a desirable new citizen has nothing to do with Masurians. It is not easy to rebuild a nation in the midst of corruption, and this is another omnipresent problem Tadeusz and Róża have to face. Tadeusz bribes a bureaucrat to get help for him and Róża so they can keep the farm. He sees a man who helps people find jobs and he advises Tadeusz to get into politics. However, that would mean working for his enemies from the past, when he fought in the AK. Tadeusz goes back to the farm and helps Róża to remove the mines from her fields. He is welcomed to stay and live there. 
Róża has been raped numerous times for being a Prussian/German. Through the director's eye, we see the Russian Army as a pack of savages. While having dinner with Tadeusz, Róża says that her dead husband was right when he said that, "[o]nly Germans see us like people". Tadeusz defends and protects Róża from her rapists and they become friends. After a while it becomes a love story, as deep as the circumstances will allow. Both of them are victims: she is a Prussian/German enemy; he is a Pole who will not accept the new communist government and has lost his wife to severe rape. They are caught in the middle of disputes, re-construction of the country, prejudices, and struggles in the communist party to consolidate power. Róża and her daughter Jadwiga try to escape from the Russians once they invaded the area in 1945, but they could not do it. Róża is raped, as was almost every woman. In the film, many Masurians start an exodus to Germany, but Róża goes back to her farm. She hides Jadwiga in the attic. On top of all the problems people have to face in the area, Poles expelled from Ukraine arrive at the farms, only to suffer even more. Here we can see that the war is not over when it is officially over, everyone has a hard time trying to adapt to a new life. They have overcome the war, but not discrimination, poverty and struggle for the land.

Some of the men who fought in the Armia Krajowa are now part of the new political system and they will invite Tadeusz to join them or he will end up in jail, but he refuses their invitation. This makes him a potential enemy of the new communist government. In order to be a part of the new country, people are expected to be Polish as well as support the communist system and the Russian authorities. The Lutheran Pastor gives us an insight to the situation of the Masurians. They had to learn German, become Lutherans and adopt German culture. The Germans destroyed their identity and now "Poles are finishing the job". Kwiatkowski (Róża's husband) and his daughter Jadwiga are being investigated to determine whether they are good or bad people. If Jadwiga and Róża are not eligible to be Polish, they will be deported. The only chance they have to stay on the farm is by registering as Poles and having Tadeusz live there. Another alternative that would make things easier for Tadeusz, Róża and Jadwiga is if Tadeusz works for the government. Far from doing this, Tadeusz is the hero, the Pole that will be faithful to his nation, his motherland and will not participate in this alliance between the traitor Poles and the Russians.

In Darkness is a story that takes place in Lwów, now Lviv in Ukraine. The director takes us to a Polish city under German occupation where we can see women who try to run away from German soldiers are all killed in front of Poldek, the protagonist. This aggravates the already bad and dangerous situation in which the Poles have been functioning, where each person has to look after him/herself; it is useless to try and save others as they try to stay alive. Smarzowski introduces us to the life of a man who works in the sewer system in Lwów, the city taken by the Germans. In one of the scenes we can see Jews in the ghetto cutting holes in the floor so that they can go down and hide in the sewers.

To survive, people have to smuggle items and money. They buy supplies from those who live outside the ghetto. In the first minutes of the film, Jews are humiliated and tortured by German soldiers while others can only watch. Germans here are also portrayed as savages. We see a Rabbi forced to dance on top of a barrel as Nazis laugh at him. When the Jews in the ghetto finally make a hole in the ground and reach the sewers, they see Poldek and Szczepek. If they are caught, they will be killed. After a few seconds of tense silence, one 
of the Jews offers Poldek a Swiss watch. Poldek takes it and says that he would get more money if he turns the Jews in, but eventually he takes the watch. Poldek asks for 500 złotych (Polish currency) plus the watch. Poldek and Szczepek are burglars: they break into houses and take whatever they can sell on the black market. Therefore, taking money from Jews is now part of the way they live. They know the sewage system and it offers a place to hide. At some point, Poldek and Szczepek get to enter the ghetto and see the living conditions of the Jews. They have no alternative but to agree and take the risk; they are taken to the sewers and are left in a filthy but secure place. As Poldek and Szczepek get out of the ghetto, Poldek says he should have asked for more.

These characters will help construct the identity of Poles. Poldek is a thief, but he will help Jews. He and his wife Wanda are concerned about the Jews and will do what they can to save them. Wanda is an important character because she is Poldek's conscience, the Polish mother that will teach that all people are equal and that Jews are not different. Although Poldek is a thief and a blackmailer, in the end he will show he has a good heart. One would think that he will sell the Jews to the Germans sooner or later, but he does not. Just like Tadeusz, Poldek finds an old friend who is now an Army officer. Both Bortnick and Poldek were in jail and Poldek was the only person who could be trusted. Bortnick brags about his privileges as an officer and says he can help his friends now. Again, we can see the growing corruption and the importance of the foreign authorities imposed by the enemy, but both Poles in Lwów and Poles in Masuria are good people who help those in greater danger.

As we come to see the life of the Jews and Poles, the director takes us to a world where little could be done to help others, but when the ghetto is evacuated and people are taken to the concentration camps, Poldek and Szczepek run to the area where the Jews are. Chaos and desperation cause the Jews to try to escape; dozens run to the sewers and Poldek agrees to help them. Szczepek wants to get out of the situation, but Poldek will not listen and he concentrates on the people he has to save. This is the beginning of 14 months of darkness in the sewers darkness that will help Jews survive, at least for a while.

Poldek shows them the way to a hideout full of filth and rats, but it is a safe place. At one point he is caught by soldiers, but he says he knows Bortnik (the Ukrainian officer). He is taken to him and Bortnik saves his life. Bortnik wants to know if Poldek saw Jews in the sewers and Poldek says that he has seen only bodies that blocked the sewers, but none of them were alive. This is an important moment in the film because Poldek faces the dilemma of turning in the Jews or helping them at the risk of being killed if he is caught doing so. Bortnik tells him that he should tell him if he sees Jews down there trying to hide, that it is his duty. Here we see the good Pole willing to risk his life for Jews in order to save their lives when it was thought to be impossible.

When the Jews are taken to a concentration camp, Poldek goes back home and lets his wife give him a nice warm bath. Poldek tells Wanda about the rewards that people are getting for turning in Jews. "Some people are making a pile" he says. Wanda replies, "God will punish their greed". When Poldek says that the Jews killed Jesus, the son of God, Wanda replies, "It is the church's politics, Jews are just the same as us. Our Lady and the apostles, they're all Jews. Even Jesus". Poldek forgets about the 500 złotych per Jew and, through this scene Holland portrays Poles as people who helped Jews when they could. 
Down in the sewers, things for the Jews can only get worse, but Poldek manages to find food and protect them even when Bortnik goes down with him to look for them. Poldek knows where they are, but he does not turn them in. Wanda is the exemplary Polish woman who does not want a better life at the expense of vulnerable people. She is mad at Poldek because he has been taking advantage of the victims. And again when Poldek shows her the jewelry he got from the Jews, she refuses to take it. As Poldek helps Pirate to look for a little girl outside the sewers, another Pole who works in a factory refuses to accept money from Poldek; he helps the Jew just because it is the right thing to do and he says "God will repay me". This makes Poldek see the contrast between him (accepting payment) and a Pole with no interest in making money off of fugitives. Despite the risks and everything Poldek has done the Jews constantly insult him, but Poldek will not leave them to die and ends up paying with his own money for their food. When the war is over and the Germans leave, he runs to get them out of the sewers and shouts, "these are my Jews, they are my work!"

Now that Poland is an autonomous and independent country, films are helping to re-build the idea of a nation in order to unify its citizens. After the escape from Russian domination, films like these propose the new Pole, the real Pole, and they reinterpret the history of the country. Nationalism is an instrument to invent nations, to artificially construct them. It is a "sentiment" (Gellner 2006), the sentiment of anger after the war and the Russian occupation. Polish culture and the idea of a nation is proposed as the result of people who are good. It uses the Catholic religion as part of the social construct and is an important element in Polish life. According to the new idea in films, people who are different can be respected and can be citizens of the country. Ethnic boundaries are built with negative consequences, but good Poles did not agree with them; they were imposed by the Germans and Russians.

\section{FINAL THOUGHTS}

Films help construct national identity by rewriting History. Their characters will tell who the real Polish citizens are and will silence the idea that they did not help the Jews or other peoples. History has provided peoples with identity and a sense of belonging. Social groups read about their history, repeat it, and retell it stressing the symbolic events and characters that give sense to their existence. For human groups, the truth is not important; researching and digging in the past is not something they do. Historians reinterpret history and look for evidence, but they are not necessarily read by common people. According to E. Florescano (2012), history provides human beings with identity and a sense of belonging: it legitimizes the possession of the territory. It helps justifying the national projects and uprisings against governments. The diversity within one country disappears when the discourse finds a way to unite all of the different groups giving the idea of a common past. Historians are like "the specialist of a tribe who is in charge of telling the others what all groups need to know: 'Who are we? What are our origins? Who were our ancestors? How did we get to this point?" (Florescano 2012: 22). With the answers people can differentiate from the other by saying "I am not like him/her/ them", I am not a stranger. The official or accepted History of a nation or a group buries events and people in order to shape the idea of a tribe, ethnic group, or 
a nation and constructs the symbols that will help individuals define who they are because they are not like others. History has a goal "to seduce the imagination of men" (Florescano 2012: 23). Beliefs, attitudes and behavior models of societies derive from the idea of the past, the historical events, the peoples and civilizations that pre-existed before the formation of today's nations. When we are born, our personal story was already written in part; family members, teachers, media, monuments, architecture and so forth trigger constant messages that answer the question of who are we even before we are born.

\section{REFERENCES}

Anderson, Benedict. 1991. Imagined communities, London, UK: Verso.

Bhabha, Homi K. 1990. Introduction: narrating the nation, in: Homi K. Bhabha (ed.), Nation and Narration, USA and Canada: Routledge.

Bhabha, Homi K. 1990. DissemiNation: time, narrative, and the margins of the modem nation, in: Homi K. Bhabha (ed.), Nation and Narration, USA and Canada: Routledge.

Brown, Michael E. 2010. Causes and implications of ethnic conflict, in: Monserrat Guibernau and John Rex (ed.), The Ethnicity reader, USA: Polity Press, pp. 92-124.

Davies, Norman. 2001. Heart of Europe: The Past in Poland's Present, New York: Oxford University Press.

Davies, Norman. 2005. God's playground. A History of Poland, vol. 1-2, New York, USA: Columbia University Press.

Fenton, Steven. 2010. Ethnicity, Cambridge, UK: Polity Press.

Florescano, Enrique. 2012. La función social de la historia, Mexico: Fondo de Cultura Económica.

Gellner, Ernest. 2006. Nations and Nationalism, Oxford, UK: Blackwell Publisher Ltd.

Gellner, Ernest. 2010. Nationalism as a product of industrial society, in: Monserrat Guibernau and John Rex (ed.), The Ethnicity reader, Malden, USA: Polity Press, pp. 64-79.

Giménez, Gilberto. 2007. Estudios sobre la cultura y las identidades sociales, México: Conaculta.

Guibernau, Montserrat and John Rex. 2010. Introduction, in: Monserrat Guibernau and John Rex (ed.), The Ethnicity reader, Malden, USA: Polity Press, pp. 1-9.

Guibernau, Montserrat. 2007. The Identity of Nations, Cambridge, UK: Polity Press.

Guibernau, Montserrat. 2013. Belonging. Solidarity and division in modern societies, Cambridge: Polity Press.

Haltof, Marek. 2012. Polish films and the Holocaust. Politics and memory, Oxford: Bergham Books.

Moyniham, Daniel. P. 1975. Ethnicity theory and experience, London: Harvard University Press.

Prazmowska, Anita J. 2011. A History of Poland, Hampshire: Palgrave MacMillan.

Wilson, Thomas M. 1999. Borders, frontiers of identity, nation and state, Oxford: Bergham Books. 
WOJNA SIĘ NIE SKOŃCZYŁA, DOPÓKI SIĘ NIE SKOŃCZYŁA.

WSPÓŁCZESNE FILMY JAKO NARZĘDZIE KONSTRUKCJI

NARODOWEJ TOŻSAMOŚCI I PAMIĘCI W POLSCE

Polski przemysł filmowy ostatnio skupia się na przedefiniowywaniu II wojny światowej i Holocaustu. Ta tematyka stale powraca w filmach, a reżyserzy stają się głosem Polaków opowiadających na nowo historię okresu Holocaustu. W artykule skupię się na tym, jak w filmach Agnieszki Holland $W$ ciemności i Wojciecha Smarzowskiego Róża zarysowany jest trudny okres powojenny, w którym Polacy są ofiarami agresji ze wschodu i z zachodu.

Żyjąc samemu w trudnych czasach, niewiele można było zrobić dla innych, np. Żydów czy Mazurów. Mimo to Polacy pomagali w miarę możliwości, chociaż groziło im uwięzienie czy rozstrzelanie. Powszechna w skali międzynarodowej pretensja, że Polacy za mało pomagali innym, bardziej cierpiącym, jest $w$ tych filmach obalona, przez pokazanie sytuacji samych Polaków. Agnieszka Holland twierdzi, że żydowscy bohaterowie u Wajdy „mają ambicję pojednania Żydów i Polaków. A on sam (Wajda) tworzy filmy ogarnięty własną obsesją winy" (Haltof 2012: 187). Wygląda na to, że Agnieszka Holland odziedziczyła po swoim nauczycielu to samo poczucie winy i teraz próbuje pojednać Żydów i Polaków. Filmy Róża i $W$ ciemności prezentują alternatywną interpretację historii Polaków podczas II wojny światowej, a oni sami są przedstawieni jako ofiary okupacji rosyjskiej i niemieckiej. W tych warunkach starają się przetrwać, ale mimo trudnej sytuacji pomagają innym na tyle, na ile jest to możliwe.

Słowa kluczowe: tożsamość narodowa, pochodzenie etniczne, historia 